\title{
Investigation of the Use of Alternative Economic Indices and QTL-Assisted Selection for the Genetic Improvement of Production and Health Traits in Bangladeshi Dairy Cattle
}

\author{
Kabirul Islam Khan MD ${ }^{1 *}$ and Raphael A Mrode ${ }^{2}$ \\ ${ }^{1}$ Department of Genetics and Animal Breeding, Chittagong Veterinary and Animal Sciences University, Chittagong, Bangladesh \\ ${ }^{2}$ Animal and Veterinary Sciences, Scotland's Rural College, Roslin Institute Building, Easter Bush, Midlothian, Edinburgh, EH25 9RG, United Kingdom
}

\begin{abstract}
The study was undertaken to investigate the use of several economic indices including QTL assisted selection for the improvement of production and health trait of dairy cattle under Bangladesh conditions. Five traits (lactation milk, fat, protein yield, somatic cell score (SCS) and direct mastitis) were simulated over 14 generations, considering three selection objectives (selection for direct mastitis; milk SCS; and the combination of direct mastitis and SCS). In addition the selection objective for SCS was simulated incorporating marker/QTL information. Genetic gains per generation for different traits were calculated by plotting the average true breeding values (TBVs) and estimated breeding values (EBVs) over generation. Selection of replacement bulls and cows were based on total merit. The genetic gains based on TBVs and EBVs of cows for milk, fat and protein yield in three selection objectives with no QTL information were similar, but gains were higher with QTL- assisted selection implemented for SCS. Genetic gains of cows for different traits based on TBVs were higher than bulls, but reverse results were obtained for bulls. The genetic trends for all traits in cows were similar in all selection objectives. However, for bulls distinct differences were observed between the QTL and no QTL-assisted selection schemes and also between SCS and the combination of SCS and direct mastitis selection objectives. Higher correlations between TBVs and EBVs for lactation milk and fat yield for both cows and bulls were found under QTL-assisted selection compared to the no QTL-assisted selection schemes. The QTL-assisted selection scheme showed higher rates of genetic gain for lactation milk, fat and protein yields than no QTL-assisted selection. However, it does not affect SCS and index values from any of the selection objectives or selection schemes. The QTL-assisted selection scheme has a positive effect on milk production and mastitis control.
\end{abstract}

Keywords: Mastitis; Breeding values; Quantitative trait loci; Selection schemes

\section{Introduction}

In Bangladesh, commercial dairy farming is increasing and the farmers rear mainly the Holstein breed and crossbreds between the Holstein and local breeds [1]. The increasing use of these breeds in farming systems is leading to higher prevalence of dairy related health problems, such as, mastitis and milk fever. Among the dairy related health problems, the prevalence of mastitis are from $19.9 \%$ (dry season) to $44.8 \%$ (wet season) in commercial dairy farming [2], while under government dairy farms it is about $25.5 \%$ [3]. Furthermore, Deshi improved varieties (Pabna and Red Chittagong cows) and local cows that produce more milk are also affected with mastitis.

Mastitis is one of the most frequent diseases affecting dairy cattle and it is a major problem in the dairy industry, leading to economic losses from the cost of treatment (antibiotics) and decreased production level (milk yield). It also increases labour and replacement costs. Mastitis is a complex disease which is caused by a number of pathogens such as, Staphylococccus aureus and Streptococcus agalactiae (both are contagious) and coliforms, streptococci and enterococci (all coming from the cows environment i.e., bedding, manure and soil). The pathogens can cause clinical mastitis, with changes in milk composition, an increase in somatic cell counts and even death. Health data in dairy cattle are routinely recorded in Denmark, Finland, Norway, and Sweden and the improvement for clinical mastitis have been included in their breeding programmes. In these countries, mastitis is indirectly selected for using somatic cell count (SCC) and also direct measures of mastitis [4].
However, the data on mastitis infection and the causal pathogen are not available in developing countries especially under Bangladesh dairy farming conditions. When real data are not available, a simulation study could be useful in designing future goals for the industry. Mastitis data was simulated by Carle' $n$ et al. [5], they considered mastitis as a binary trait and distinguished between cows with at least one case of mastitis (1) and cows without cases (0).

The average daily milk yield of improved varieties of cattle (Pabna and Red Chittagong Cows) in Bangladesh is ranging from 2.5 to 5.0 litres [6-9]. Due to the unsystematic breeding and lack of adequate knowledge on herd management by the farmers, the population of these breeds of cattle and their productivity is decreasing. However, increasing the population number and the productivity of these breeds, the available options are better management, feeding, animal health care and breeding. Among these options the breeding is a permanent and stable solution, but it requires an objective breeding goal for

*Corresponding author: Md. Kabirul Islam Khan, Department of Genetics and Animal Breeding, Chittagong Veterinary and Animal Sciences University, Chittagong-4202, Bangladesh, Tel: +88031659224; Fax: +88031 659620; E-mail:kik1775@yahoo.co.uk

Received December 29, 2016; Accepted January 18, 2017; Published January 19, 2017

Citation: Khan KI, Mrode RA (2017) Investigation of the Use of Alternative Economic Indices and QTL-Assisted Selection for the Genetic Improvement of Production and Health Traits in Bangladeshi Dairy Cattle. J Vet Sci Technol 8: 414 doi: 10.4172/2157-7579.1000414

Copyright: @ $2017 \mathrm{Khan} \mathrm{Kl}$, et al. This is an open-access article distributed under the terms of the Creative Commons Attribution License, which permits unrestricted use, distribution, and reproduction in any medium, provided the original author and source are credited. 
the whole industry [1]. Recently the government of Bangladesh has started a genetic improvement programme for increased production of milk in the subsistence farming with a traditional (progeny-testing programme) selection and mating approach. However, this method is time consuming, costly and require proper recording. But there is no well-developed recording system for dairy cattle genetic evaluation and improvement [9]. However, this improvement programme is focused only on milk yield with no attention on health traits. Among the health traits, somatic cell count is one of the traits which is much easier to record compared to mastitis for instance. Thus, a study that examines the possible consequences of an improvement programme that ignores or includes somatic cell score (SCS) in the selection objective becomes very important in the Bangladesh situation. In addition, when mastitis records are not available, the efficiency of utilising SCS with the option of incorporating marker information could be more efficient.

The process of selection for a particular trait using genetic markers, is called marker assisted selection (MAS). MAS can accelerate the rate of genetic progress by increasing the accuracy of selection and by reducing the generation interval $[1,10]$. However, the benefits of MAS are greatest for traits with low heritability. Marker identification and use should enhance future prospects for breeding of such traits as tolerance or resistance of the environmental stresses, including diseases [11]. In addition, more benefits could be expected from MAS with more specific applications, such as early selection of animals, or by the application of dynamic procedures, i.e., letting the respective weights to QTL and polygenic values in the selection criterion vary across generations. However, before incorporation of markers in a breeding programme, careful assessment is required for the potential benefits of MAS and of the design of the breeding programme [12].

Several simulation studies on the impact of using QTL information has been reported in the literature (e.g., Meuwissen and van Arendonk, [13]; Ruane and Colleau [14]; Spelman and Garrick [10]; Spelman et al. [15]; Abdel-Azim and Freeman [11]. Out of them, Spelman et al. [15] tests the additional genetic gains of MAS, and they observed limited benefit ( $1.8 \%$ genetic gain) of MAS in conventional progeny testing schemes through a deterministic approach. The available studies in the literature have used simple breeding structures and small populations with selection for a number of non-overlapping generations, however, deterministic simulation includes more realistic population structure and overlapping generations. The deterministic simulation studies reported that QTL responses from MAS schemes were higher than those from non-MAS schemes. A few studies of genetic research related to lactation and udder health has been reported [16].

Currently the experimental analysis of industry herd information is difficult due to lack of data, as there is no systematic genetic improvement programme for dairy cattle in Bangladesh. Therefore, the use of stochastic computer simulation models, according to SØrensen et al. [17], Carle'n et al. [5] would be helpful in examining the future potential genetic improvement for milk yield traits by using MAS or quantitative trait loci (QTL) assisted selection. For the achievement of this the aim of the current study was (i) to simulate a multi dairy trait model under three selection objectives using a stochastic approach; (ii) to incorporate marker/QTL information for the genetic improvement of dairy cattle; and (iii) to evaluate the different economic selection indices under QTL-assisted and no QTL- assisted selection schemes.

\section{Materials and Methods}

\section{Simulation of breeding values and phenotypic values of each trait}

A stochastic simulation study was used for multi dairy traits with mastitis liabilities under Bangladesh conditions and Pabna cattle considered as model breed. The methodology was used in developing the current simulation model (1) is based on Falconer and Mackay [18], Verrier [19] and Carle' $n$ et al. [5].

$$
\begin{aligned}
& Y_{i j k}=\mu+L_{i}+a_{j}+P_{j}+e_{i j k} \\
& \text { Where, } Y_{i j k} \text { is the individual trait value; } \\
& \mu \text { is the overall mean; } \\
& L_{i} \text { is the effect of ith lactation; } \\
& a_{j} \text { is the cows additive genetic value; } \\
& P_{j} \text { is the permanent environmental effect; and } \\
& e_{i j k} \text { is the temporary environmental effects. }
\end{aligned}
$$

The effect of dominance and epistasis was not considered in this model.

In this study, a herd consisting of 400 cows, the progeny of 80 bulls were simulated using FORTRAN 95 to mimic a situation for the improvement in a large dairy herd of Bangladesh, as data recording across herds is not established. Five traits (total lactation milk, fat and protein yields, somatic cell score and direct mastitis resistance) were simulated over 14 generations (from year 3.5 to 50 year) considering three selection objectives of milk yield (selection for direct mastitis resistance, milk somatic cell score, and the combination of direct mastitis resistance and somatic cell score), assuming an infinitesimal model. In addition somatic cell score (SCS) was simulated assuming QTL which accounted for $15 \%$ of the genetic variance. The phenotypic mean with standard deviations of five different traits and the economic values of the respective traits are presented in Table 1 . The data were derived from 270 days lactation yield and the milk payment system was on milk volume only. The direct mastitis resistance was simulated as a binary traits with underlying normally distributed liability with phenotypic means of zero and standard deviation of 1.0 (i.e., $\sim \mathrm{N}(0$, 1). The (co)variance matrices for the additive genetic (breeding values) and environmental effects (temporary and permanent) were calculated for the base population from the parameters shown in Table 2 .

The phenotypic values for the cows were created as the sum of the mean, the animal breeding value and the environmental values for the respective traits. The progeny breeding values were the sum of the sample half from each parent plus the Mendelian sampling term (which was calculated as the product of Cholesky decomposition matrix of genetic (co) variance matrix, and $\Phi_{i}$ is a vector of randomly selected pseudo-normal deviates). The base population was assumed unrelated. Seventy five percent of the base cows were selected randomly for the next lactation. The phenotypic records of cows with lactations two and three were simulated to have an increase of $20 \%$ and $25 \%$ in temporary environmental effects, respectively, compared to that of lactation one. After the third lactation, all the older cows were culled and replaced by the two years old young animals (both bulls and cows) and were used for mating and offspring production.

\section{Mating strategy and production of offspring}

Three population structures for considering direct mastitis resistance, SCS and a combination of direct mastitis resistance and SCS objectives, were simulated. The calving interval and generation interval for the cows were maintained at 1.3 and 3.5 years, respectively. From fourth to later generations (up to 14 ), $30 \%$ cows were culled in each generation and replaced with the replacement heifers. A total of 40 
Citation: Khan KI, Mrode RA (2017) Investigation of the Use of Alternative Economic Indices and QTL-Assisted Selection for the Genetic Improvement of Production and Health Traits in Bangladeshi Dairy Cattle. J Vet Sci Technol 8: 414. doi: 10.4172/2157-7579.1000414

Page 3 of 12

\begin{tabular}{|c|c|c|c|}
\hline Traits & Mean with standard deviations & Economic values (US\$) & References \\
\hline Milk yield $(\mathrm{Kg})$ & $1782.29 \pm 262.5$ & 0.39 & Khan et al. \\
\hline Fat yield $(\mathrm{Kg})$ & $77.74 \pm 9.1$ & -0.52 & Khan \\
\hline Protein yield (Kg) & $71.42 \pm 8.7$ & -0.29 & \\
\hline Somatic cell score & $3.09 \pm 0.6$ & -3.97 & Wolfová et al. \\
\hline Mastitis & $0 \pm 1.0$ & -3.97 & Carle'n et al. \\
\hline
\end{tabular}

Table 1: Mean with standard deviations and economic values (US\$) of different traits

\begin{tabular}{|c|c|c|c|c|c|}
\hline & 'MY & ${ }^{1} \mathrm{FY}$ & ${ }^{1} \mathrm{PY}$ & ${ }^{2} \mathrm{SCC}$ & ${ }^{3}$ Mastitis \\
\hline MY & 0.26 & 0.63 & 0.59 & -0.13 & 0.2 \\
\hline FY & 0.57 & 0.27 & 0.79 & 0 & 0 \\
\hline PY & 0.46 & 0.82 & 0.25 & 0 & 0 \\
\hline SCS & 0.14 & 0 & 0 & 0.08 & 0.07 \\
\hline Mastitis & 0.36 & 0 & 0 & 0.67 & 0.03 \\
\hline
\end{tabular}

Table 2: Heritabilities (bold), genetic correlations (lower diagonal) and phenotypic correlations (upper diagonal) of the different traits.

bulls (12 older bulls and 28 young bulls) were used for mating from fourth to later (up to 14) generations by natural mating.

The matings was random, hierarchical straight breeding. In all generations, the calving rate and survivability for bulls and cows were maintained at $65 \%$ and $90 \%$, respectively. The sex ratio for the offspring was maintained as 1:1 for males to females.

\section{Genetic evaluation, construction of selection index and calculation of genetic gains}

Estimated breeding values (EBVs) were obtained from a multitrait animal repeatability model according to Meuwissen et al. [20] and Mrode [21] and the model of analysis can be presented as:

$$
\mathrm{Y}=\mathrm{Xb}+\mathrm{Za}+\mathrm{Wpe}+\mathrm{e}
$$

where, $\mathrm{Y}$ is the traits yield;

$\mathrm{e}$ is the vector of error terms;

a is the vector of animal breeding value, random;

$\mathrm{b}$ is a vector of fixed effects (lactation), used in the simulation model;

pe is the vector of random permanent environmental effect and non-additive genetic effects, which are independently distributed with means of zero and variance $\sigma_{\mathrm{pe}}^{2}$ and $\sigma_{\mathrm{e}}^{2}$, respectively;

$\mathrm{X}, \mathrm{Z}$ and $\mathrm{W}$ are incidental matrices relating records to fixed, animals and permanent environmental effects; respectively.

$\operatorname{var}(\mathrm{pe})=\mathrm{P}$ where $\mathrm{P}$ is the $(\mathrm{co})$ variance matrix between permanent environmental effects

$\operatorname{var}(\mathrm{e})=\mathrm{I} \sigma_{\mathrm{e}}^{2}=\mathrm{R}$

$\operatorname{var}(\mathrm{a})=\mathrm{AG}$, where $\mathrm{G}$ is the (co)variance matrix and;

$$
\operatorname{var}(\mathrm{y})=\mathrm{ZAZ} \mathrm{Z}^{\prime} \mathrm{G}+\mathrm{WPW}+\mathrm{R}
$$

and the mixed model equation become:

$\left[\begin{array}{ccc}X^{\prime} X & X^{\prime} Z & X^{\prime} W \\ Z^{\prime} X & Z^{\prime} Z+A^{-1} G & Z^{\prime} W \\ W^{\prime} X & W^{\prime} Z & W^{\prime} W+P\end{array}\right]\left[\begin{array}{c}\hat{b} \\ \hat{a} \\ p e\end{array}\right]=\left[\begin{array}{c}X^{\prime} y \\ Z^{\prime} y \\ W^{\prime} y\end{array}\right]$

Selection was based on the computed total economic index values, for bulls, heifers and cows. In the case of young animals (heifers and bulls) selection was based on the total economic index using parent averages. The total economic merit was the sum of the product of EBVs and the economic value (Table 1) for all traits: Total economic merit $(\mathrm{T})=\sum \mathrm{a}_{\mathrm{i}} \mathrm{G}_{\mathrm{i}}$, where, $\mathrm{a}_{\mathrm{i}}$ 's and $\mathrm{G}_{\mathrm{i}}$ 's are the economic and the breeding values, respectively, for the different traits, expressed in dollar (US\$).

The asymptotic genetic gain for this population was derived by calculating the generation-by-generation change in the averages of phenotypic and genetic values (based on true and estimated breeding values).

\section{Selection of males and females using different scenarios}

In this study, the milk yield, fat yield, protein yield, somatic cell scores (SCS) and directs mastitis resistance was simulated. The selection of males and females to be parents was done according to 6 scenarios: (1) Considering milk yield, fat yield, protein yield and SCS in the index and observing the change in mastitis resistance as it was in the simulation, but not selected for in the objective; (2) Considering milk yield, fat yield, protein yield and mastitis resistance in the index and observing the change in SCS as it was in the simulation, but not selected for in the objective; (3) Considering milk yield, fat yield, protein yield, SCS and mastitis resistance in the index; (4) Considering milk yield, fat yield, SCS and QTL explaining 15\% of the additive variance in SCS in the index and observing the change in mastitis resistance as it was in the simulation, but not selected for in the objective; (5) Considering milk yield, fat yield, SCS and QTL explaining $25 \%$ of the additive variance in SCS in the index and observing the change in mastitis as it was in the simulation, but not selected for in the objective; and (6) Considering milk yield, fat yield and protein yield and observing the change in SCS and mastitis resistance as they were in the simulation, but not selected for in the objective.

\section{Comparison of selection objectives and selection schemes by Pearson correlation coefficient}

The comparison of three different selection objectives and QTLassisted and no QTL-assisted selection schemes was done by the Pearson correlation coefficient between true breeding values (TBVs) and estimated breeding values (EBVs). Furthermore, the average values for TBVs and EBVs for different traits on both cows and bulls were plotted over generations to estimate the response (genetic gains). These estimated rate response values were also used for comparing the different selection objectives and selection schemes. 
Citation: Khan KI, Mrode RA (2017) Investigation of the Use of Alternative Economic Indices and QTL-Assisted Selection for the Genetic Improvement of Production and Health Traits in Bangladeshi Dairy Cattle. J Vet Sci Technol 8: 414. doi: 10.4172/2157-7579.1000414
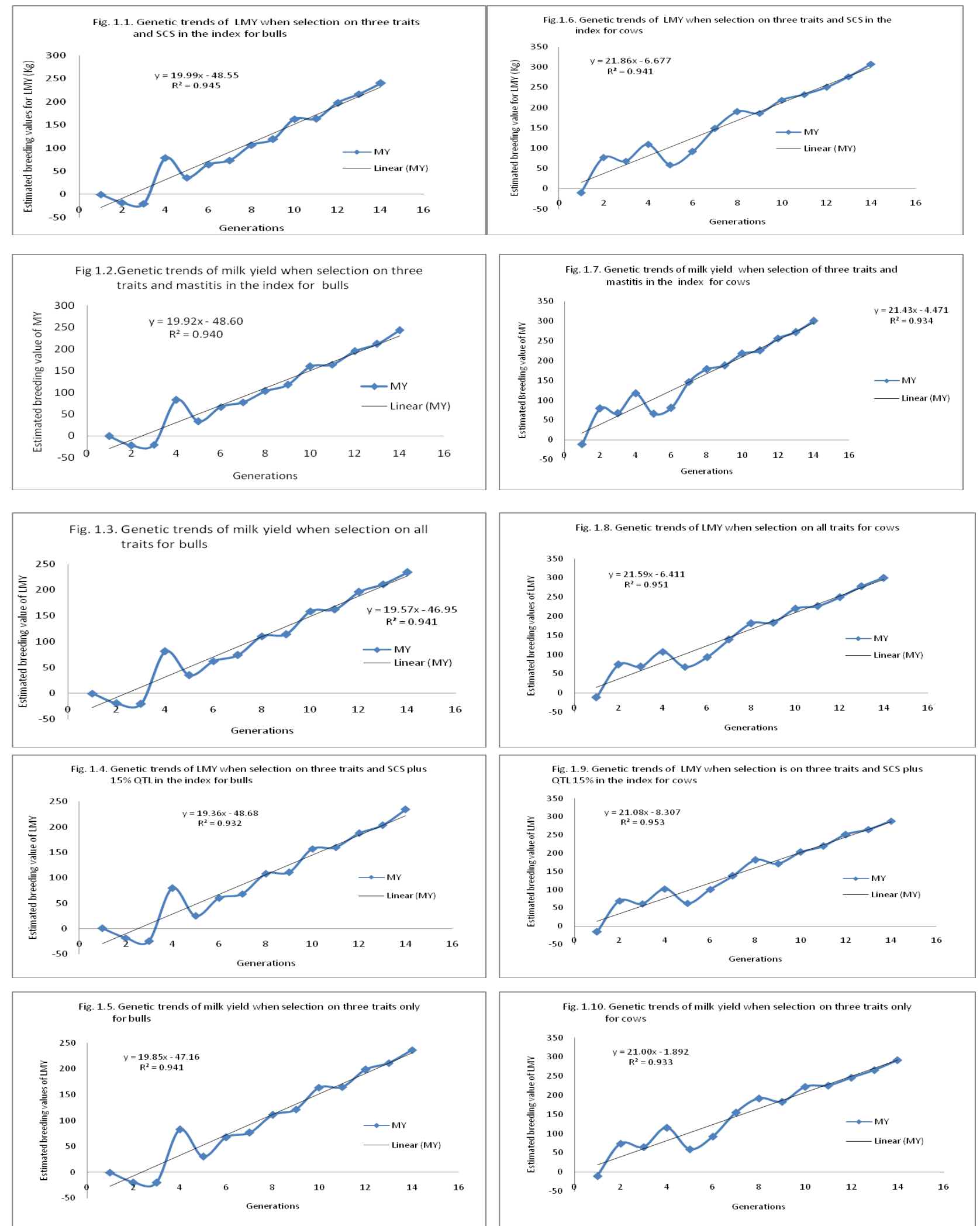

Figure 1: Genetic trends of lactation milk yield (LMY) when selecting on production (milk, fat and protein yields), mastitis resistance and somatic cell score (SCS) with or without QTL assisted selection for bulls and cows per generation, based on different selection scenarios. 


\section{Statistical Analysis}

All combinations were simulated with ten replicates. From this data the average genetic merit for animals born within a generation was calculated. Results from all simulation models were analysed by using Proc GLM and Proc MIXED of SAS (SAS v.9.2, 2008). The differences of values between different mastitis liabilities scenarios and selection schemes were tested with the probability value of $\mathrm{P} \leq 0.05$.

\section{Results and Discussion}

Means with standard errors of phenotypic and genetic gains $\left(\sigma_{g}\right)$ in Kg per generation, based on true breeding values (TBVs) and estimated breeding values (EBVs) for the different traits, under three different mastitis liabilities, with total merit (economic selection index) in QTLassisted and no QTL assisted selection schemes as selection objective, for cows and bulls, respectively, are presented in Tables 3 and 4.

Table 3 indicates that the phenotypic gains for all the traits of cows in the three different selection objectives under the no QTL-assisted selection scheme were similar. The phenotypic gains for all traits under the selection objective SCS of cows of the different selection schemes, were similar, therefore the selection schemes no QTL-assisted and QTL-assisted selection had no significant differences $(\mathrm{P}<0.05)$ with regards to genetic gains in the different traits (Table 3 ). However, based on EBVs, the genetic gains for all the traits were higher than the values based on TBVs and phenotypic values, but statistically no significant differences were found for cows as well as bulls. Based on EBVs, the genetic gains for milk yield, fat yield and protein yield were higher than the gains that were calculated for the selection based on TBVs and phenotypic values, for both cows and bulls, but no statistical significant differences were observed. Genetic gains were differed by the differences of selection objectives were reported by SØrensen et al. [22], Lessen et al. [23].

However, the gains based on EBVs for milk yield, fat yield and protein yield was higher in the no QTL-assisted selection scheme than the $15 \%$ and $25 \%$ QTL-assisted selection schemes when selecting for low SCS, but no significant differences were observed. Similarly, under the QTL-assisted selection scheme the genetic gains of all the traits for bulls were higher than when no QTL is fixed for SCS, but no significant differences were obtained. The genetic gains for milk yield under no QTL-assisted selection per year in the three different selection objectives were from 0.75 to $0.79 \%$ for cows and 0.73 to $0.85 \%$ for bulls. These values were lower than those published by Lee et al. [24]; Andrabi and Moran [25,26]. They obtained annual genetic progress for milk yield of 1 to $2 \%$. The genetic gains for the economic index were similar in all selection objectives and also for both the QTLassisted and no QTL-assisted selection schemes. The genetic gains of SCS were found to be similar for the QTL-assisted and no QTL-assisted selection schemes and between the three different selection objectives. The genetic gains for economic merit of all selection objectives and also between the QTL-assisted and no QTL-assisted selection schemes were statistically similar. The higher genetic gains in the different traits under the QTL-assisted selection scheme were attributed to the effect of polygenes and QTL. Abdel-Azim and Freeman [26] found that QTLassisted selection was superior to no QTL assisted selection.

The genetic gains of bulls for the different traits based on TBVs (Table 4) were higher compared to that of the cows (Table 3) under the no QTL and QTL assisted selection schemes, but reverse scenarios was found for selection based on EBVs. However, although higher gains was found for selection based on EBV compared to that based on TBVs for cows, similar genetic gains were observed for bulls for the same scenarios. The differences in genetic gains for the different traits between selection based on TBVs or EBVs, might be due to the effects of inclusion of fixed and random factors, and also taken into account when using true breeding vales in the animal model for the estimation of breeding values. Furthermore, the differences of genetic gains in the different traits between cows and bulls might be due to the differences of sexes and also the effects of differences in selection intensity. The genetic gains can be differed by the animal model parameters, selection intensities and with the differences of sexes were mentioned by other researchers (Israel and Weller [27], Ntombizakhe Mpotu et al. [28]).

The changing genetic gain of a particular generation born cows and bulls (all) in average phenotypic values, average true breeding values, average estimated breeding values $(\mathrm{Kg})$ and average economic merit (US\$), when selection was based on estimated breeding values, for the different traits were plotted. The trends for all the traits in all three mastitis liabilities scenarios under QTL-assisted and no QTL-assisted selection schemes were similar. Therefore, for example, only the lactation milk yield, total economic merit, direct mastitis resistance and somatic cell score trends over 14 generations of selection and mating for both cows and bulls based on EBVs, are shown in Figures 1-4.

From Figure 1 (Figure 1.6-1.10), it can be seen that the trends for lactation milk yield in all three selection objectives under the QTLassisted and no QTL-assisted selection schemes for cows, were similar. In the first three generations, the genetic gains were negative and in the fourth generation a sharp increased rate can be observed, followed by a decreased rate in the fifth generation. However, from generations 6 to 14 a steady increased genetic rate can be seen. The base cows were used for the progeny production up to generation 3 and in generation 4 all the base cows were replaced by the replacement heifers. Thereafter, $30 \%$ of the cows were replaced each year up to 14 generations. This might be the cause for the fluctuations in the genetic gain with the increases of generation number. Similar causes were identified by Dzama et al. [29] for stochastic simulation studies.

In the cases of bulls (Figure 1.1-1.5), the rate of genetic gains was negative in generation 1 , but in generation 2 a rapid increase and from generations 3 to 5 a fluctuating rate can be observed. However, from generation 6 onwards steady increase can be seen. The fluctuation of the genetic gains might be due to the bulls used in those years. In the first 2 years, the base bulls were used and in generation 3 selected young bulls were used. The higher genetic gains were obtained in generation 4 onwards might be the effects of specific sire and dam matings in those generations. That sire and dam have a positive effect on increase in genetic gain, were reported by Dzama et al. [29]; Andabi and Moran [25].

The average total economic merit (Figure 2) and the genetic gains for direct mastitis resistance (Figure 3) for both cow and bull trends, were similar to that of Figure 1 for lactation milk yield, in all the mastitis scenarios under both QTL-assisted and no QTL-assisted selection schemes. The fluctuations in the trend might be attributed to similar causes as that of the genetic gains in Figure 1. However, the trend pattern for the genetic gains of somatic cell score were different for cows and bulls under the no QTL-assisted selection scheme and it also differed between the QTL-assisted and no QTL-assisted selection schemes (Figure 4). Under the no QTL-assisted selection scheme, for cows the somatic cell score rate of genetic gains between somatic cell score and the combination of direct mastitis resistance and somatic cell score mastitis resistance scenarios were similar, but it was different from the QTL-assisted selection scheme of somatic cell score mastitis 
Citation: Khan KI, Mrode RA (2017) Investigation of the Use of Alternative Economic Indices and QTL-Assisted Selection for the Genetic Improvement of Production and Health Traits in Bangladeshi Dairy Cattle. J Vet Sci Technol 8: 414. doi: 10.4172/2157-7579.1000414

Page 6 of 12

\begin{tabular}{|c|c|c|c|c|c|}
\hline \multirow{3}{*}{ Based on } & \multirow{3}{*}{ Selection scheme } & \multirow{3}{*}{ Traits } & \multicolumn{3}{|c|}{ Selection objectives } \\
\hline & & & Direct Mastitis & scs & $\begin{array}{c}\text { Combination of direct mastitis } \\
\text { and SCS }\end{array}$ \\
\hline & & & $\Delta \mathbf{g}$ & $\Delta \mathbf{g}$ & $\Delta \mathbf{g}$ \\
\hline \multirow[t]{2}{*}{$\begin{array}{l}\text { True Breeding } \\
\text { Values }\end{array}$} & \multirow{6}{*}{ No QTL -assisted } & MY & $25.98 \pm 3.304$ & $26.29 \pm 2.634$ & $25.98 \pm 3.637$ \\
\hline & & FY & $0.38 \pm 0.164$ & $0.40 \pm 0.145$ & $0.40 \pm 0.211$ \\
\hline \multirow{4}{*}{ (TBV's) } & & PY & $0.21 \pm 0.155$ & $0.29 \pm 0.176$ & $0.26 \pm 0.188$ \\
\hline & & Mas & $0.019 \pm 0.010$ & $0.019 \pm 0.011$ & $0.018 \pm 0.011$ \\
\hline & & SCS & $0.009 \pm 0.007$ & $0.010 \pm 0.011$ & $0.007 \pm 0.008$ \\
\hline & & Elndex & $9.80 \pm 1.250$ & $9.92 \pm 1.028$ & $9.75 \pm 1.318$ \\
\hline & \multirow{6}{*}{$\begin{array}{l}\text { QTL-assisted } \\
(15 \%)\end{array}$} & MY & & $25.06 \pm 2.694$ & \\
\hline & & FY & & $0.39 \pm 0.115$ & \\
\hline & & PY & & $0.26 \pm 0.148$ & \\
\hline & & Mas & & $0.017 \pm 0.006$ & \\
\hline & & SCS & & $0.008 \pm 0.006$ & \\
\hline & & Elndex & & $9.49 \pm 1.108$ & \\
\hline & \multirow{6}{*}{$\begin{array}{l}\text { QTL-assisted } \\
(25 \%)\end{array}$} & MY & & $26.50 \pm 3.229$ & \\
\hline & & FY & & $0.41 \pm 0.198$ & \\
\hline & & PY & & $0.32 \pm 0.211$ & \\
\hline & & Mas & & $0.017 \pm 0.006$ & \\
\hline & & SCS & & $0.010 \pm 0.006$ & \\
\hline & & Elndex & & $10.03 \pm 1.294$ & \\
\hline & \multirow{6}{*}{ QTL-assisted } & MY & & $25.48 \pm 3.129$ & \\
\hline & & FY & & $0.34 \pm 0.194$ & \\
\hline & & PY & & $0.21 \pm 0.194$ & \\
\hline & & Mas & & $0.018 \pm 0.009$ & \\
\hline & & SCS & & $0.009 \pm 0.007$ & \\
\hline & & Elndex & & $9.70 \pm 1.151$ & \\
\hline \multirow{24}{*}{$\begin{array}{l}\text { Estimated Breeding } \\
\text { Values (EBV's) }\end{array}$} & \multirow{6}{*}{ No QTL- assisted } & MY & $30.01 \pm 4.262$ & $27.99 \pm 2.972$ & $30.23 \pm 4.402$ \\
\hline & & FY & $0.46 \pm 0.142$ & $0.43 \pm 0.107$ & $0.46 \pm 0.176$ \\
\hline & & PY & $0.28 \pm 0.131$ & $0.29 \pm 0.129$ & $0.31 \pm 0.155$ \\
\hline & & Mas & $0.011 \pm 0.003$ & $0.011 \pm 0.004$ & $0.011 \pm 0.004$ \\
\hline & & SCS & $0.008 \pm 0.005$ & $0.008 \pm 0.007$ & $0.006 \pm 0.006$ \\
\hline & & Elndex & $11.33 \pm 1.628$ & $11.55 \pm 1.349$ & $11.39 \pm 1.641$ \\
\hline & \multirow{6}{*}{$\begin{array}{c}\text { QTL-assisted } \\
(15 \%)\end{array}$} & MY & & $29.52 \pm 3.257$ & \\
\hline & & FY & & $0.47 \pm 0.105$ & \\
\hline & & PY & & $0.32 \pm 0.141$ & \\
\hline & & Mas & & $0.011 \pm 0.003$ & \\
\hline & & SCS & & $0.008 \pm 0.005$ & \\
\hline & & Elndex & & $11.18 \pm 1.301$ & \\
\hline & \multirow{6}{*}{$\begin{array}{l}\text { QTL-assisted } \\
(25 \%)\end{array}$} & MY & & $30.92 \pm 3.848$ & \\
\hline & & FY & & $0.48 \pm 0.163$ & \\
\hline & & PY & & $0.34 \pm 0.192$ & \\
\hline & & Mas & & $0.012 \pm 0.002$ & \\
\hline & & SCS & & $0.008 \pm 0.006$ & \\
\hline & & Elndex & & $11.71 \pm 1.507$ & \\
\hline & \multirow{6}{*}{ QTL-assisted } & MY & & $29.41 \pm 2.691$ & \\
\hline & & FY & & $0.42 \pm 0.169$ & \\
\hline & & PY & & $0.26 \pm 0.153$ & \\
\hline & & Mas & & $0.011 \pm 0.003$ & \\
\hline & & SCS & & $0.007 \pm 0.005$ & \\
\hline & & Elndex & & $11.18 \pm 1.028$ & \\
\hline
\end{tabular}

$\mathrm{MY}=$ Milk yield, $\mathrm{FY}=$ Fat yield, $\mathrm{PY}=$ Protein yield, Mas=Direct mastitis resistance, $\mathrm{SCS}=$ Somatic Cell Score, Elndex=Economic selection index, and $\mathrm{QTL}=\mathrm{Quantitative} \mathrm{trait}$ Loci; Means with superscript $a$ and $b$ are different at $5 \%$ level of significance between selection objective with in a generation and between selection schemes within selection objectives.

Table 3: Mean with standard error of genetic gain $(\Delta \mathrm{g})$ in $\mathrm{Kg}$ per generation for different traits under three different mastitis liabilities with total merit in QTL-assisted and no QTL assisted selection schemes as selection objective, for cows. 
Citation: Khan KI, Mrode RA (2017) Investigation of the Use of Alternative Economic Indices and QTL-Assisted Selection for the Genetic Improvement of Production and Health Traits in Bangladeshi Dairy Cattle. J Vet Sci Technol 8: 414. doi: 10.4172/2157-7579.1000414

Page 7 of 12

\begin{tabular}{|c|c|c|c|c|c|}
\hline \multirow{3}{*}{ Based on } & \multirow{3}{*}{ Selection scheme } & \multirow{3}{*}{ Traits } & \multicolumn{3}{|c|}{ Selection objectives } \\
\hline & & & Direct Mastitis & scs & $\begin{array}{l}\text { Combination of direct mastitis } \\
\text { and SCS }\end{array}$ \\
\hline & & & $\Delta \mathrm{g}$ & $\Delta \mathrm{g}$ & $\Delta \mathrm{g}$ \\
\hline \multirow{24}{*}{$\begin{array}{l}\text { True Breeding } \\
\text { Values (TBV's) }\end{array}$} & \multirow{6}{*}{ No QTL assisted } & MY & $28.27 \pm 2.255$ & $28.35 \pm 2.759$ & $27.93 \pm 2.821$ \\
\hline & & $\mathrm{FY}$ & $0.42 \pm 0.140$ & $0.43 \pm 0.112$ & $0.43 \pm 0.142$ \\
\hline & & PY & $0.25 \pm 0.112$ & $0.29 \pm 0.126$ & $0.28 \pm 0.129$ \\
\hline & & Mas & $0.018 \pm 0.006$ & $0.009 \pm 0.008$ & $0.019 \pm 0.009$ \\
\hline & & scs & $0.008 \pm 0.005$ & $0.018 \pm 0.009$ & $0.007 \pm 0.005$ \\
\hline & & Elndex & $10.66 \pm 0.835$ & $10.71 \pm 1.025$ & $10.49 \pm 1.033$ \\
\hline & \multirow{6}{*}{$\begin{array}{l}\text { QTL-assisted } \\
\qquad(15 \%)\end{array}$} & MY & & $27.75 \pm 2.310$ & \\
\hline & & $\mathrm{FY}$ & & $0.45 \pm 0.101$ & \\
\hline & & PY & & $0.29 \pm 0.127$ & \\
\hline & & Mas & & $0.017 \pm 0.007$ & \\
\hline & & SCS & & $0.007 \pm 0.006$ & \\
\hline & & Elndex & & $10.51 \pm 0.924$ & \\
\hline & \multirow{6}{*}{$\begin{array}{l}\text { QTL-assisted } \\
\quad(25 \%)\end{array}$} & MY & & $28.46 \pm 2.216$ & \\
\hline & & $\mathrm{FY}$ & & $0.45 \pm 0.142$ & \\
\hline & & PY & & $0.33 \pm 0.173$ & \\
\hline & & Mas & & $0.017 \pm 0.006$ & \\
\hline & & scs & & $0.008 \pm 0.006$ & \\
\hline & & Elndex & & $10.77 \pm 0.893$ & \\
\hline & \multirow{6}{*}{ QTL-assisted } & MY & & $28.22 \pm 3.304$ & \\
\hline & & $\mathrm{FY}$ & & $0.40 \pm 0.178$ & \\
\hline & & PY & & $0.24 \pm 0.154$ & \\
\hline & & Mas & & $0.018 \pm 0.008$ & \\
\hline & & scs & & $0.007 \pm 0.006$ & \\
\hline & & Elndex & & $10.73 \pm 1.216$ & \\
\hline \multirow{24}{*}{$\begin{array}{l}\text { Estimated Breeding } \\
\text { Values (EBV's) }\end{array}$} & \multirow{6}{*}{ No QTL assisted } & MY & $27.87 \pm 3.010$ & $27.99 \pm 2.972$ & $27.40 \pm 3.363$ \\
\hline & & $\mathrm{FY}$ & $0.41 \pm 0.130$ & $0.43 \pm 0.107$ & $0.42 \pm 0.133$ \\
\hline & & PY & $0.25 \pm 0.113$ & $0.29 \pm 0.129$ & $0.27 \pm 0.122$ \\
\hline & & Mas & $0.011 \pm 0.003$ & $0.011 \pm 0.004$ & $0.01 \pm 0.003$ \\
\hline & & $\operatorname{scs}$ & $0.007 \pm 0.004$ & $0.008 \pm 0.007$ & $0.006 \pm 0.004$ \\
\hline & & Elndex & $10.54 \pm 1.144$ & $10.58 \pm 1.109$ & $10.32 \pm 1.258$ \\
\hline & \multirow{6}{*}{$\begin{array}{l}\text { QTL-assisted } \\
\qquad(15 \%)\end{array}$} & MY & & $27.11 \pm 2.781$ & \\
\hline & & FY & & $0.43 \pm 0.105$ & \\
\hline & & PY & & $0.26 \pm 0.123$ & \\
\hline & & Mas & & $0.010 \pm 0.003$ & \\
\hline & & $\operatorname{scs}$ & & $0.006 \pm 0.005$ & \\
\hline & & Elndex & & $10.28 \pm 1.103$ & \\
\hline & \multirow{6}{*}{$\begin{array}{l}\text { QTL-assisted } \\
\quad(25 \%)\end{array}$} & MY & & $28.00 \pm 2.885$ & \\
\hline & & FY & & $0.42 \pm 0.142$ & \\
\hline & & PY & & $0.30 \pm 0.175$ & \\
\hline & & Mas & & $0.011 \pm 0.002$ & \\
\hline & & SCS & & $0.007 \pm 0.005$ & \\
\hline & & Elndex & & $10.62 \pm 1.134$ & \\
\hline & \multirow{6}{*}{ QTL-assisted } & MY & & $27.80 \pm 2.831$ & \\
\hline & & $\mathrm{FY}$ & & $0.39 \pm 0.161$ & \\
\hline & & PY & & $0.24 \pm 0.145$ & \\
\hline & & Mas & & $0.010 \pm 0.003$ & \\
\hline & & scs & & $0.006 \pm 0.005$ & \\
\hline & & Elndex & & $10.57 \pm 1.065$ & \\
\hline
\end{tabular}

Traits descriptions are same as footnote on Table 3; Means with superscript a and b are different at $5 \%$ level of significance between selection objective within a generation and between selection schemes within selection objectives.

Table 4: Means with standard errors for genetic gain $(\Delta \mathrm{g})$ in $\mathrm{Kg}$ per generation for different traits under three different mastitis liabilities with total merit as selection objective, for bulls. 
Citation: Khan KI, Mrode RA (2017) Investigation of the Use of Alternative Economic Indices and QTL-Assisted Selection for the Genetic Improvement of Production and Health Traits in Bangladeshi Dairy Cattle. J Vet Sci Technol 8: 414. doi: 10.4172/2157-7579.1000414

Page 8 of 12

\begin{tabular}{|c|c|c|c|c|c|c|c|}
\hline \multirow{3}{*}{$\begin{array}{l}\text { Selection } \\
\text { scheme }\end{array}$} & \multirow[b]{3}{*}{ Traits } & \multicolumn{3}{|c|}{ Cow } & \multicolumn{3}{|c|}{ Bull } \\
\hline & & \multicolumn{3}{|c|}{ Selection objectives } & \multicolumn{3}{|c|}{ Selection objectives } \\
\hline & & Direct mastitis & scs & $\begin{array}{l}\text { Combination of } \\
\text { direct mastitis } \\
\text { and SCS }\end{array}$ & Direct mastitis & scs & $\begin{array}{l}\text { Combination of } \\
\text { direct mastitis and } \\
\text { SCS }\end{array}$ \\
\hline \multirow{6}{*}{$\begin{array}{l}\text { No QTL } \\
\text { assisted }\end{array}$} & MY & 0.9 & 0.89 & 0.89 & 0.94 & 0.92 & 0.92 \\
\hline & $\mathrm{FY}$ & 0.77 & $0.76 \pm 0.01$ & $0.77 \pm 0.01$ & $0.82 \pm 0.01$ & $0.79 \pm 0.01$ & $0.76 \pm 0.01$ \\
\hline & PY & 0.72 & 0.72 & 0.72 & $0.76 \pm 0.01$ & $0.74 \pm 0.01$ & $0.66 \pm 0.02$ \\
\hline & Mas & $0.67 \pm 0.01$ & $0.67 \pm 0.01$ & $0.67 \pm 0.01$ & $0.70 \pm 0.01$ & $0.71 \pm 0.01$ & $0.71 \pm 0.01$ \\
\hline & scs & $0.57 \pm 0.01$ & $0.59 \pm 0.01$ & $0.57 \pm 0.00$ & $0.51 \pm 0.03$ & $0.62 \pm 0.02$ & $0.56 \pm 0.01$ \\
\hline & Elndex & 0.9 & 0.9 & 0.9 & 0.94 & 0.92 & 0.92 \\
\hline \multirow{6}{*}{$\begin{array}{c}\text { QTL-assisted } \\
\quad(15 \%)\end{array}$} & MY & & 0.9 & & & 0.92 & \\
\hline & $\mathrm{FY}$ & & 0.77 & & & $0.79 \pm 0.01$ & \\
\hline & PY & & $0.71 \pm 0.01$ & & & $0.73 \pm 0.01$ & \\
\hline & Mas & & $0.64 \pm 0.01$ & & & $0.67 \pm 0.02$ & \\
\hline & scs & & $0.54 \pm 0.01$ & & & $0.59 \pm 0.02$ & \\
\hline & Elndex & & 0.9 & & & 0.92 & \\
\hline \multirow{6}{*}{$\begin{array}{c}\text { QTL-assisted } \\
(25 \%)\end{array}$} & MY & & 0.9 & & & 0.92 & \\
\hline & $\mathrm{FY}$ & & 0.77 & & & $0.79 \pm 0.01$ & \\
\hline & PY & & $0.72 \pm 0.01$ & & & $0.70 \pm 0.02$ & \\
\hline & Mas & & $0.66 \pm 0.01$ & & & $0.70 \pm 0.01$ & \\
\hline & scs & & $0.55 \pm 0.01$ & & & $0.63 \pm 0.02$ & \\
\hline & Elndex & & 0.9 & & & 0.92 & \\
\hline \multirow{6}{*}{$\begin{array}{l}\text { QTL-assisted } \\
\text { (Milk, fat and } \\
\text { Protein) }\end{array}$} & MY & & 0.9 & & & 0.93 & \\
\hline & $\mathrm{FY}$ & & $0.76 \pm 0.01$ & & & $0.75 \pm 0.01$ & \\
\hline & PY & & $0.70 \pm 0.00$ & & & $0.67 \pm 0.01$ & \\
\hline & Mas & & $0.68 \pm 0.01$ & & & $0.70 \pm 0.02$ & \\
\hline & scs & & $0.59 \pm 0.01$ & & & $0.53 \pm 0.02$ & \\
\hline & Elndex & & 0.9 & & & 0.93 & \\
\hline
\end{tabular}

Traits descriptions are same as footnote on Table 3; Means with superscript a and b are different at $5 \%$ level of significance between selection objectives within a generation and between selection schemes within selection objectives and between cows and bulls.

Table 5: Correlations for the estimated breeding values of different traits under three different selection objectives for cows and bulls.

liabilities scenario. Up to generation 4 the rate was similar, after that a steady increased rate can be observed, but at generation 14 , the rate suddenly dropped. In the case of bulls, distinct differences were observed between the QTL-assisted and no QTL-assisted selection schemes and also between somatic cell score and the combination of somatic cell score and direct mastitis liabilities scenarios. The differences in the rate of genetic gains for somatic cell score might be due to the QTL-assisted selection that was considered on the somatic cell score basis. Traits that considered QTL-assisted selection have an impact on genetic gains, as were reported by Abdel-Azim and Freeman [11].

Correlations for the estimated breeding values of different traits under the three different selection objectives for cows and bulls under quantitative trait loci (QTL) assisted (15\% and 25\%) and no QTLassisted selection schemes are presented in Table 5. The correlations for milk yield (0.89 to 0.94$)$, fat yield ( 0.76 to 0.82$)$, protein yield (0.66 to 0.72$)$, direct mastitis resistance $(0.67$ to 0.71$)$, somatic cell score $(0.51$ to 0.62$)$ and for the economic selection index $(0.90$ to $0.94)$ for all selection objectives and selection schemes were similar for both cows and bulls (Table 5). The correlations of different traits in cows and bulls was hierarchical among traits, that is milk yield $>$ fat yield $>$ protein yield $>$ direct mastitis resistance $>$ SCS, except for the combination of direct mastitis resistance and SCS in bulls where direct mastitis resistance correlations were higher than that of protein. The correlations of the economic selection index between the different selection objectives of cows and bulls are similar, but bulls had higher values than cows for both the QTL and no QTL assisted selection schemes. Furthermore, the correlations of the economic selection index under SCS between no QTL and QTL assisted selection are also similar. The higher correlation value indicated that the bulls were superior to cows. On the other hand Carlen et al. [5] observed the correlation for lactation was 0.76 for and for 150 days milk yield but these values are lower than the $t$ value for milk yield in this study.

\section{Conclusion}

It can be seen that the rate of genetic gains for milk -, fat and protein yields were similar for cows and bulls in the three different selection objectives under the no QTL-assisted and QTL-assisted selection schemes. However, direct mastitis resistance differed between the selection objectives and schemes. In this study, the QTL-assisted selection scheme has a low impact somatic cell scores. This might be due to low phenotypic variation with low heritability for somatic cell scores. However, the QTL-assisted selection scheme has a positive effect on milk production and mastistis control. This study offered an opportunity to utilise somatic cell score as an indirect trait for mastitis control, which leads to a higher milk yield and increase the genetic gains. However, this study can be widely used under practical situations for genetic improvement of dairy cows.

\section{Acknowledgements}

The authors are very much grateful to the Commonwealth Scholarship Commission for providing the fellowship to the first author. They also like to thanks to the Scottish Agricultural College, Edinburgh, United Kingdom for their active cooperation and support to pursue this study. 
Citation: Khan KI, Mrode RA (2017) Investigation of the Use of Alternative Economic Indices and QTL-Assisted Selection for the Genetic Improvement of Production and Health Traits in Bangladeshi Dairy Cattle. J Vet Sci Technol 8: 414. doi: 10.4172/2157-7579.1000414
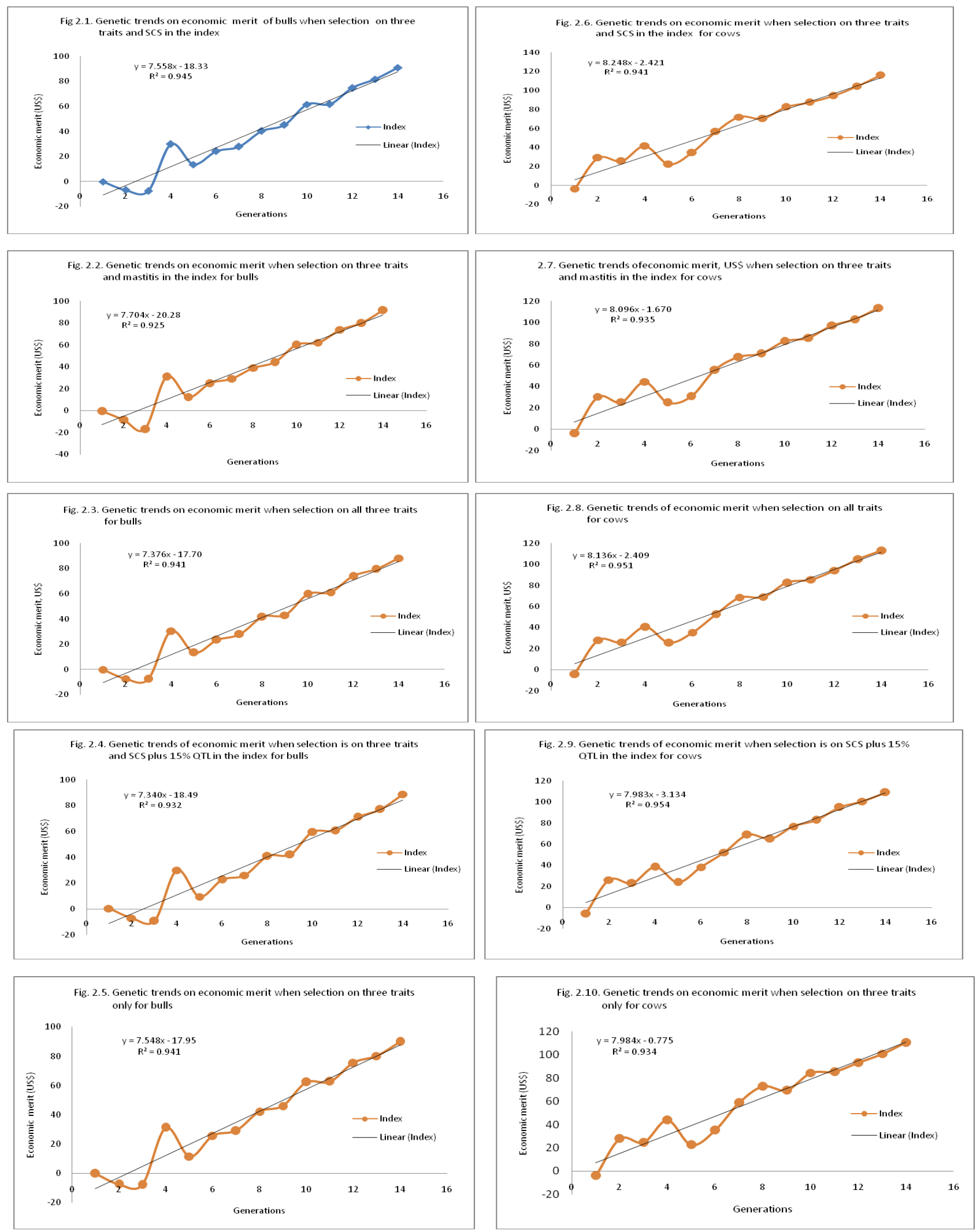

Figure 2: Genetic trends of average total economic merit (US\$) when selecting on production (milk, fat and protein yields), mastitis and somatic cell score (SCS) with or without QTL assisted selection for bulls and cows per generation, based on different selection scenarios. 
Citation: Khan KI, Mrode RA (2017) Investigation of the Use of Alternative Economic Indices and QTL-Assisted Selection for the Genetic Improvement of Production and Health Traits in Bangladeshi Dairy Cattle. J Vet Sci Technol 8: 414. doi: 10.4172/2157-7579.1000414
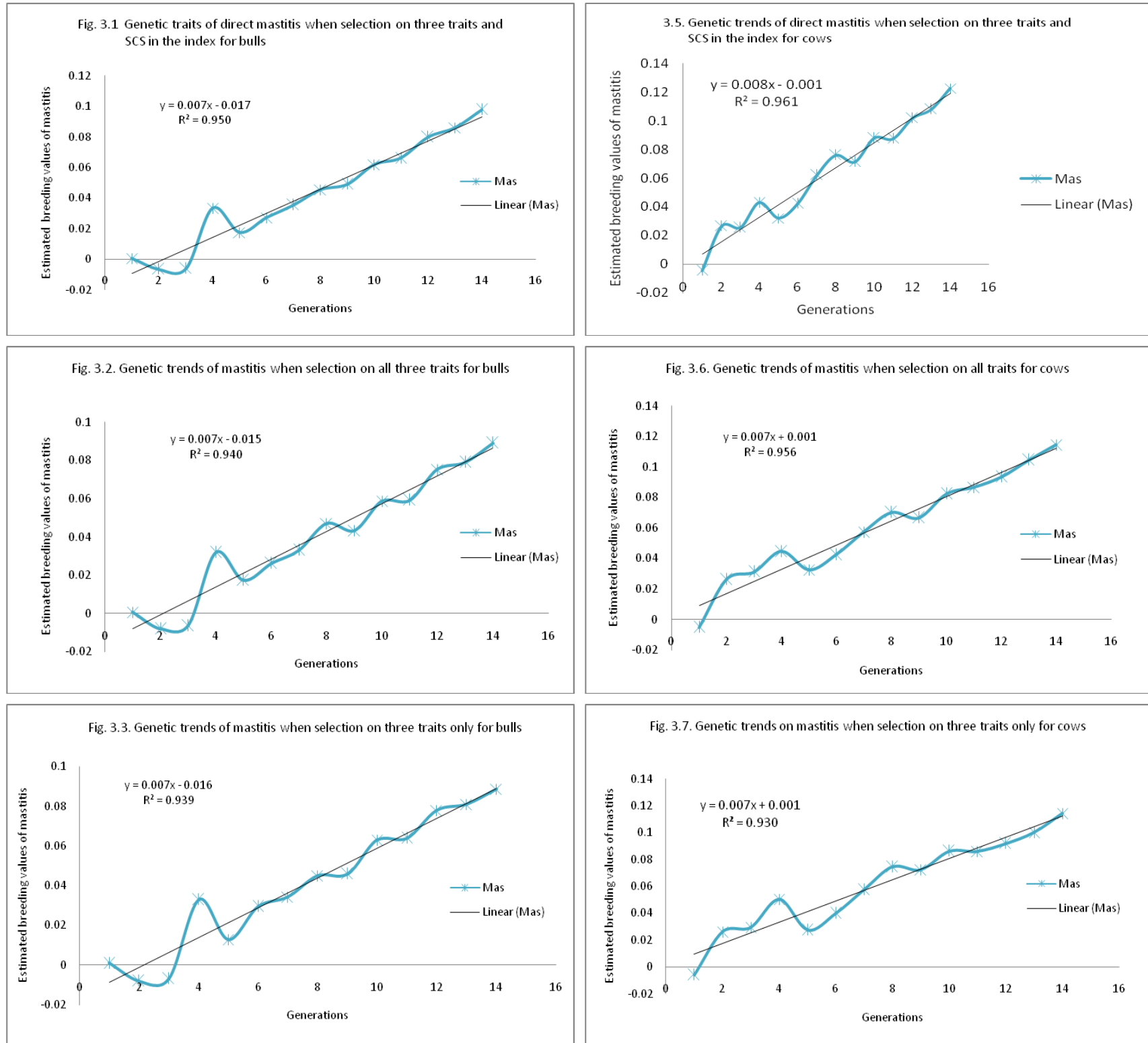

Fig. 3.7. Genetic trends on mastitis when selection on three traits only for cows
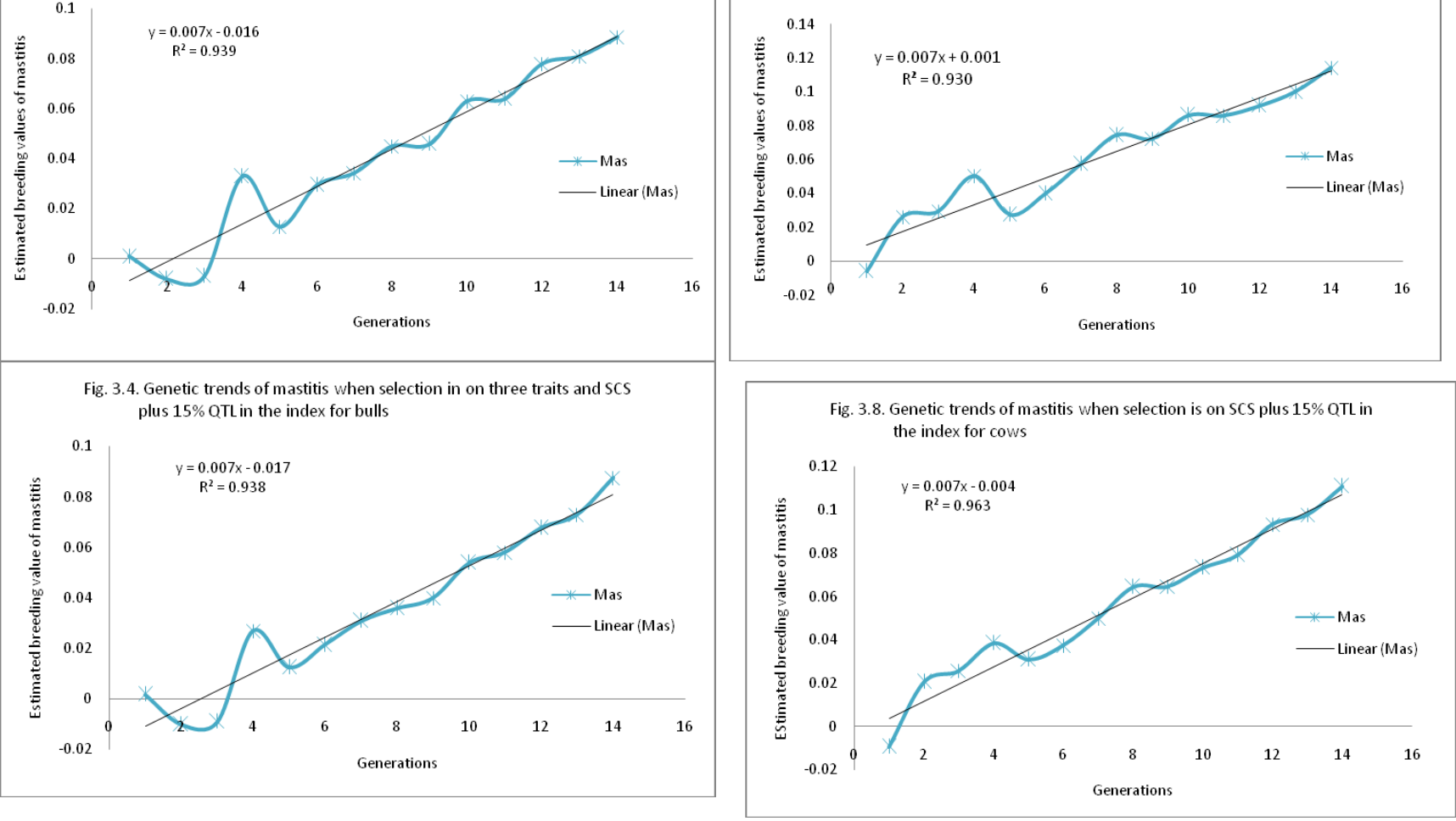

Figure 3: Genetic trends of direct mastitis resistance when selecting on production (milk, fat and protein yields), mastitis and somatic cell score (SCS) with or without QTL assisted selection for bulls and cows per generation, based on different selection scenarios. 
Citation: Khan KI, Mrode RA (2017) Investigation of the Use of Alternative Economic Indices and QTL-Assisted Selection for the Genetic Improvement of Production and Health Traits in Bangladeshi Dairy Cattle. J Vet Sci Technol 8: 414. doi: 10.4172/2157-7579.1000414
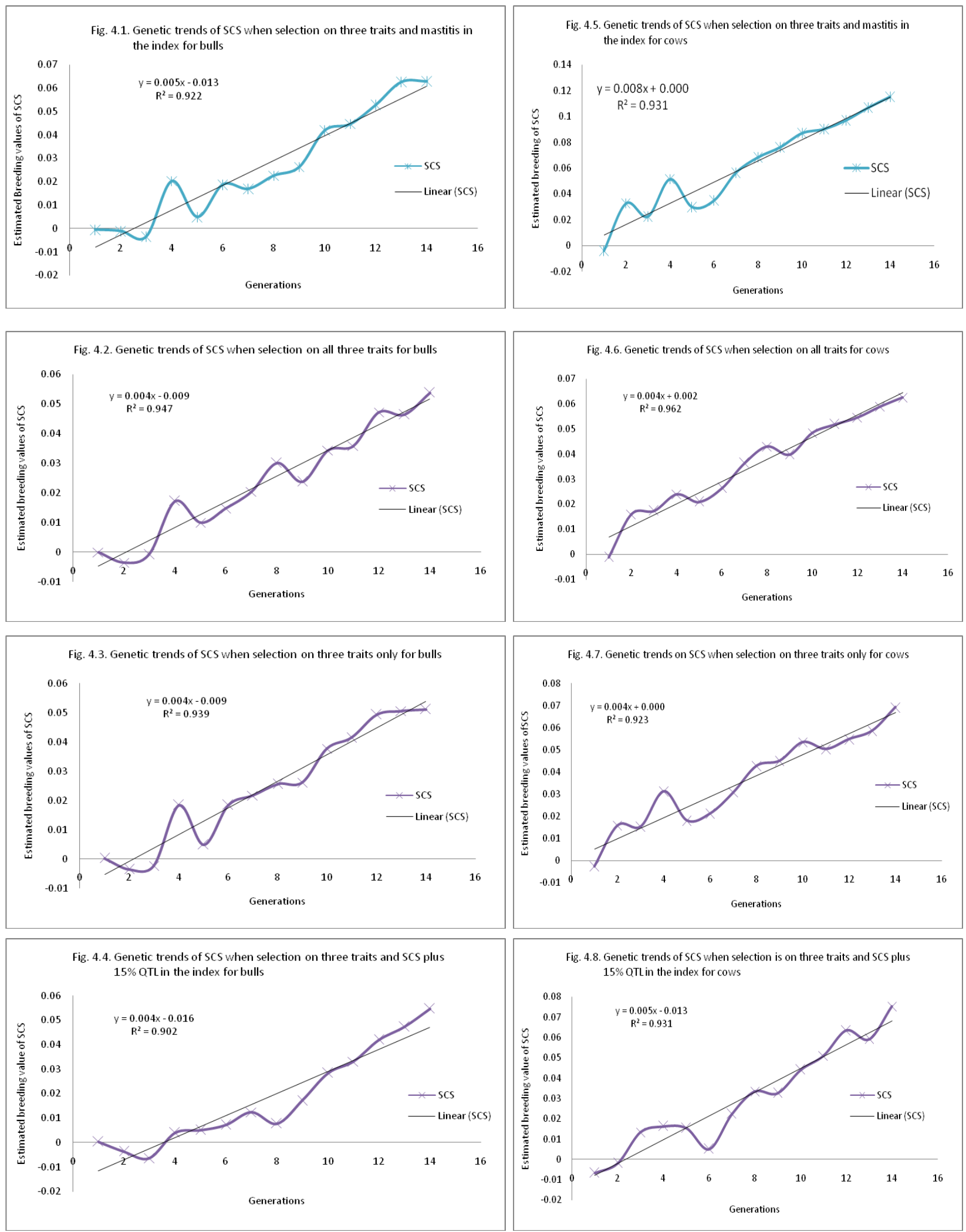

Figure 4: Genetic trends of somatic cell score when selection on production (milk, fat and protein yields), mastitis and somatic cell score (SCS) with or without QTL assisted selection for bulls and cows per generation, based on different selection scenarios. 
Citation: Khan KI, Mrode RA (2017) Investigation of the Use of Alternative Economic Indices and QTL-Assisted Selection for the Genetic Improvement of Production and Health Traits in Bangladeshi Dairy Cattle. J Vet Sci Technol 8: 414. doi: 10.4172/2157-7579.1000414

\section{References}

1. Khan MKI, Blair HT, Lopez-Villalobos N, Johnson PL (2005) Productive reproductive and economic performance of dairy cattle in Bangladesh. Proc Assoc Advance Anim Breed Genetic 16: 124-127.

2. Rhaman MA, Bhuiyan MMU, Kamal MM, Shamsuddin M (2009) Prevalence and risk factors of mastitis in dairy cows. Bangladesh Veterinarian 26: 54-60.

3. Uddin MA, Kamal MM, Haque ME (2009) Epidemiological study of udder and treat diseases in dairy cows. Bangladesh J Vet Medicin 7: 332-340.

4. Charfeddine N, Alenda R, Groen AF, Carabaño MJ (2000) Genetic parameters and economic values of lactation somatic cell score and production traits. J Dairy Sci 83: 84-91.

5. Carle'n E, Emanuelson U, Strandberg E (2006) Genetic evaluation of mastitis in dairy cattle using linear models, threshold models, and survival analysis: A simulation study. J Dairy Sci 89: 4049-4057.

6. Majid MA, Nahar TN, Talukdar Al, Rahman MA (1998) Reproductive performance of purebred $F_{1}, F_{2}$ and $F_{3}$ cows raised in Savar dairy farm. Bangladesh J Livest Res 2: 63-71.

7. Khan MKI, Huque KS, Miah AG, Khatun MJ (2000) Study on the performance of Red Chittagong cows under different production system. Pakistan J Biol Sci 3: 318-319.

8. Bhuiyan AKFH, Shahjalal M, Islam MN, Rahman AKMA, Keown JF, et al. (2008) Characterzation, conservation and improvement of Red Chittagong Cattle of Bangladesh. In Proceeding of the USDA Project Review Workshop. Vol. 1, pp: 26-28

9. Khan MKI, Blair HT, Lopez-Villalobos N (2012) Lactation curves of different cattle breeds under cooperative dairying conditions in Bangladesh. J Appl Anim Res 40: 179-185.

10. Spelman RJ, Garrick DJ (1997) Utilisation of marker assisted selection in a commercial dairy cow population. Livest Prod Sci 47: 139-147.

11. Abdel-Azim G, Freeman AE (2002) Superiority of QTL-assisted selection in dairy cattle breeding schemes. J Dairy Sci 85: 1869-1880.

12. Dekkers JCM (2007) Estimation of economic values for dairy cattle breeding goals: bias due to sub-optimal management policies. Livest Prod Sci 29: 131 149.

13. Meuwissen THE, van Arendonk JAM (1992) Potential improvement in rate of genetic gain from marker-assisted selection in dairy cattle breeding schemes. J Dairy Sci 75: 1651-1659.
14. Ruane J, Colleau JJ (1996) Marker assisted selection for a sex limited character in a nucleus breeding population. J Dairy Sci 79: 1666-1678.

15. Spelman RJ, Garrick DJ, van Arendonk JAM (1999) Utilisation of genetic variation by marker-assisted selection in commercial dairy cattle populations. Livest Prod Sci 59: 51-60.

16. Shook GE (2006) Major advances in determining appropriate selection goals J Dairy Sci 89: 1349-1361.

17. SØrensen JT, Kristensen ES, Thysen I (1992) A stochastic model simulating the dairy herd on a PC. Agric Syst 39: 177-200.

18. Falconer DS, Mackay TFC (1997) Introduction to quantitative genetics. 4th edn Longmans Green, Harlow, Essex, UK, pp: 122-159.

19. Verrier E (2001) Marker assisted selection for the improvement of two antagonistic traits under mixed inheritance. Genet Sel Evol 33: 17-38.

20. Meuwissen THE, Hayes B, Goddard ME (2001) Prediction of total genetic value using genome-wide sense marker maps. Genet Sel Evol 28: 161-176.

21. Mrode MR (2005) Use of genetic markers in prediction of breeding values Linear models for the prediction of animal breeding values. 2nd edn, pp: 163-191.

22. SØrensen MK, Berg P, Jensen J, Christensen LG (2006) Stochastic simulation of breeding schemes for total merit in dairy cattle. Interbull Bulletin 23: 183.

23. Lassen J, SØrensen MK, Madsen P, Ducrocq V (2007) A stochastic simulation study on validation of an approximate multitrait model using pre-adjusted data for prediction of breeding values. J Dairy Sci 90: 3002-3011.

24. Lee KL, Freeman AE, Johnson IP (1998) Estimation of genetic change in the registered Holstein cattle population. J Dairy Sci 68: 2629-2638.

25. Andrabi SMH, Moran C (2007) Selection of dairy cow bulls for artificial insemination. Intl J Agric Biol 9: 175-178.

26. Abdel-Azim G, Freeman AE (2003) Effects of including a Quantitative Trait Locus in selection under different waiting plans of young bulls. J Dairy Sci 86 667-676.

27. Israel C, Weller Jl (2000) Effect of misidentification on genetic gain and estimation of breeding value in dairy cattle populations. J Dairy Sci 83: 181-187.

28. Ntombizakhe M, Charles S, Edward BB (1993) Breeding strategies for genetic improvement of dairy cattle in Zimbabwe. I. Genetic Evaluation. J Dairy Sci 76: 1163-1172.

29. Dzama K, Walter JP, Ruvuna F, Sanders JO, Chimonyo M (2001) Index selection of beef cattle for growth and milk production using computer simulation modelling. South African J Anim Sci 31: 65-75. 